\title{
Government Policy Model to Actualize Adiwiyata School in Pasangkayu Regency
}

\author{
Abidin \\ \{abidinpdil@gmail.com\} \\ Universitas Brawijaya, Indonesia
}

\begin{abstract}
Environmental condition become more worst due to population growth and climate change, so it's required environmental management steps in the process. Environmental education is one step that can reduce and minimize the impact of environmental damage that has occurred. To realize the environmental education, the government through the Ministry of Environment and Forestry made a program called Adiwiyata which is regulated in Ministry of Environment Regulation No. 5 of 2013. The purpose of this research is to create a policy model of school programs (elementary and junior high schools) in Pasangkayu Regency in developing the Adiwiyata Model. This research was used descriptive qualitative approach, and the model was build using the flowchart model. There are two models developed in this research, the model which is related to the synergy of the government and the general public and the synergy of the government and the school. The purpose of model 1 is to create a community that cares about the environment and the purpose of model 2 is to educate young people to become individuals who care and are able to protect the surrounding environment. The model of policies and actions that can be taken by the Pasangkayu Regency Government is to synergize local government policies with the community and schools to encourage the emergence of people who care about the environment so that they can reach the standards of Adiwiyata in accordance with applicable regulations.
\end{abstract}

Keywords: Adiwiyata, Environment, Policy, Synergy.

\section{Introduction}

Environmental condition become more worst due to population growth and climate change, so it requires environmental management steps in the process. Environmental management must be able to influence daily life and human habits. One of the government's steps to realized more proper environmental management to protect the environment from damage is through education, especially environmental education [1]. Environmental education is a factor that able to minimize environmental damage and increase understanding about environment, awareness, and participation of community to overcome environmental problems [2]. Through, environmental education was one of the factors that can be used to solving problem related to environmental issues [3].

The realization of environmental education is an initiation of Adiwiyata's program. Adiwiyata's program is one of the joint programs that held by Ministry of Environment and Ministry of National Education in order to educate and give an awareness of citizen in school about how important to conserve the environment. In this program each of school citizen can involve in so many school activities to create healthy environment and to prevent environment 
negative impact [4]. Adiwiyata's program is one of government commitment in environmental management and protection through education. Policies made by the government through Peraturan Menteri Lingkungan Hidup Nomor 5 Tahun 2013 have been translated into Adiwiyata school programs.

In the implementation, Ministry of Environment and Ministry of National Education has to collaborate with stakeholders to execute this program, also can push every school to implement Adiwiyata's program using environmental lesson and carry out more environmental based activities as first step to educate school citizen in order to conserve surrounding environment. The purpose of Adiwiyata's program is to create more responsible school citizen in order to conserve the environment through good school governance that support sustainable development. So, in the future, school citizen can be contributed more in conserving the environment, not only in school but in their daily life. Adiwiyata contains four main components that are comprehensive for realizing schools that are cultured in the environment, not only in terms of the physical school but from the behavior of the school community [5].

There is some standard in Adiwiyata's program and that was based on Peraturan Menteri Lingkungan Hidup Nomor 5 Tahun 2013. Furthermore, there are four categories with each of categories has two standards. (1) Environmental policy has standard Education Level Curriculum (KTSP) must contain environmental protection and management effort and School Budget and Activity Planning (RKAS) must have a program about environmental protection and management. (2) Implementation of environment-based curriculum has standard that teacher must able to develop environmental study activities and children can do an environmental protection and management activity. (3) Participatory based environment activities have standard carry out planned environmental protection and management activity for school citizen and collaborate with government, private, media, another school, and citizen in order to do an environmental protection and management. (4) Management of environemtal friendly supporting facilities have standard that school must have environmentally friendly supporting facilities and increase the quality of environmentally friendly supporting facilities management.

Pasangkayu Regency was the new regency located in Northern of South Sulawesi Province. This regency was created from Mamuju Regency. The policies in Pasangkayu Regency must reflect the goal of being able to preserve and protect the environment, so that they will indirectly be able to assist in the optimal process of developing Adiwiyata schools. Currently in Pasangkayu Regency, there is one environmental policy made by government that is North Mamuju Regency Regulation Number 25 of 2011 concerning waste service levies Regulation of the North Mamuju Regency Number 9 of 2014 concerning the instructions for implementing the North Mamuju Regional Regulation Number 25 of 2011 concerning Waste Service/Sanitation Service Levies. To develop a policy that can make the Adiwiyata Model more reliable, there are actually two important aspects, namely synergy with the community and with the school. According to Sulistyowati [6], there are at least three pillars in education that are school, family, and community. So, involvement of these elements to make government policy and realized Adiwiyata model will be very influential. The purpose of this research is to create a policy model of school programs (elementary and junior high schools) in Pasangkayu Regency in developing the Adiwiyata Model. 


\section{Material and Method}

\subsection{Study Area}

This research was conducted in the Pasangkayu Regency, with an approximately area of $3,043.75 \mathrm{~km}^{2}$. Pasangkayu Regency with the capital city of Pasangkayu, was the youngest district and located in the northern part of West Sulawesi. This regency was the result of division from Mamuju Regency. In 2007 the administration was divided into 11 districts, consisting of 63 villages (Figure 1). The vision of pasangkayu district was the realization of a prosperous, advanced, and dignified Pasangkayu community based on diversity, while the mission was specifically divided into three namely Welfare Missions, Progress Missions, and Missions for Dignity.

\subsection{Data Collection}

This research was used descriptive qualitative approach, and the model was build using the flowchart model. Data was obtained by interviewing 4 key informants in charge of their fields, consisting of the Head of the Pasangkayu Regency Regional Development Planning Board, the Head of the Pasangkayu Regency Environmental Agency, the Head of the Pasangkayu Regency Education and Sports Office, and the Second Assistant for the Economy and Development Sector of the Pasangkayu Regency Government.

\subsection{Data Analysis}

The interview data was used as a part of flowchart model. According to Lofland et al [7], Flowchart were very useful to assist in the process of conceptualization and initial planning, the advantages of this model where it can be used as an appropriate means to present conclusions from the analysis that has been done. The flowchart model was build based on the result of interview and Peraturan Menteri Lingkungan Hidup nomor 5 tahun 2013 on Adiwiyata Guidelines.

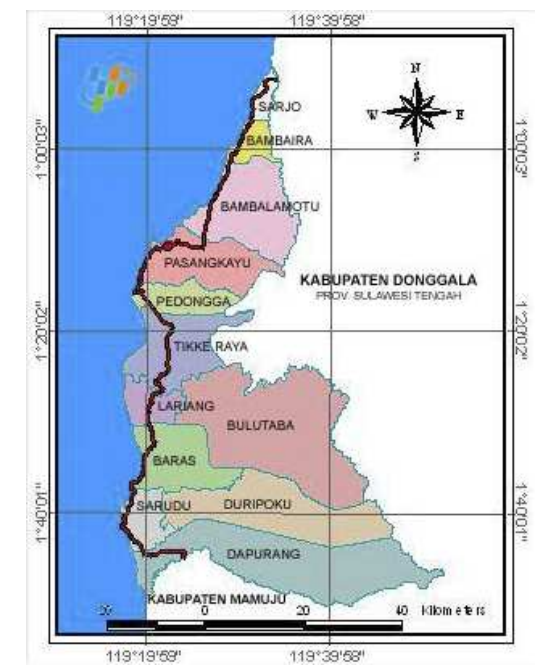

Fig. 1. Administrative Map of Pasangkayu Regency. 


\section{Result and Discussion}

Adiwiyata School Model was made based on several supporting variables for the Adiwiyata school that had been modified to be more specific. The Adiwiyata school model must be adaptable to the 4 standards listed in Peraturan Menteri Lingkungan Hidup nomor 5 tahun 2013 on Adiwiyata Guidelines. The standard consists of environmentally friendly policies, implementation of an environment-based curriculum, participatory-based environmental activities, and management of environmentally friendly supporting facilities. These four standards have been outlined in the two models in Figure 2 and Figure 3.

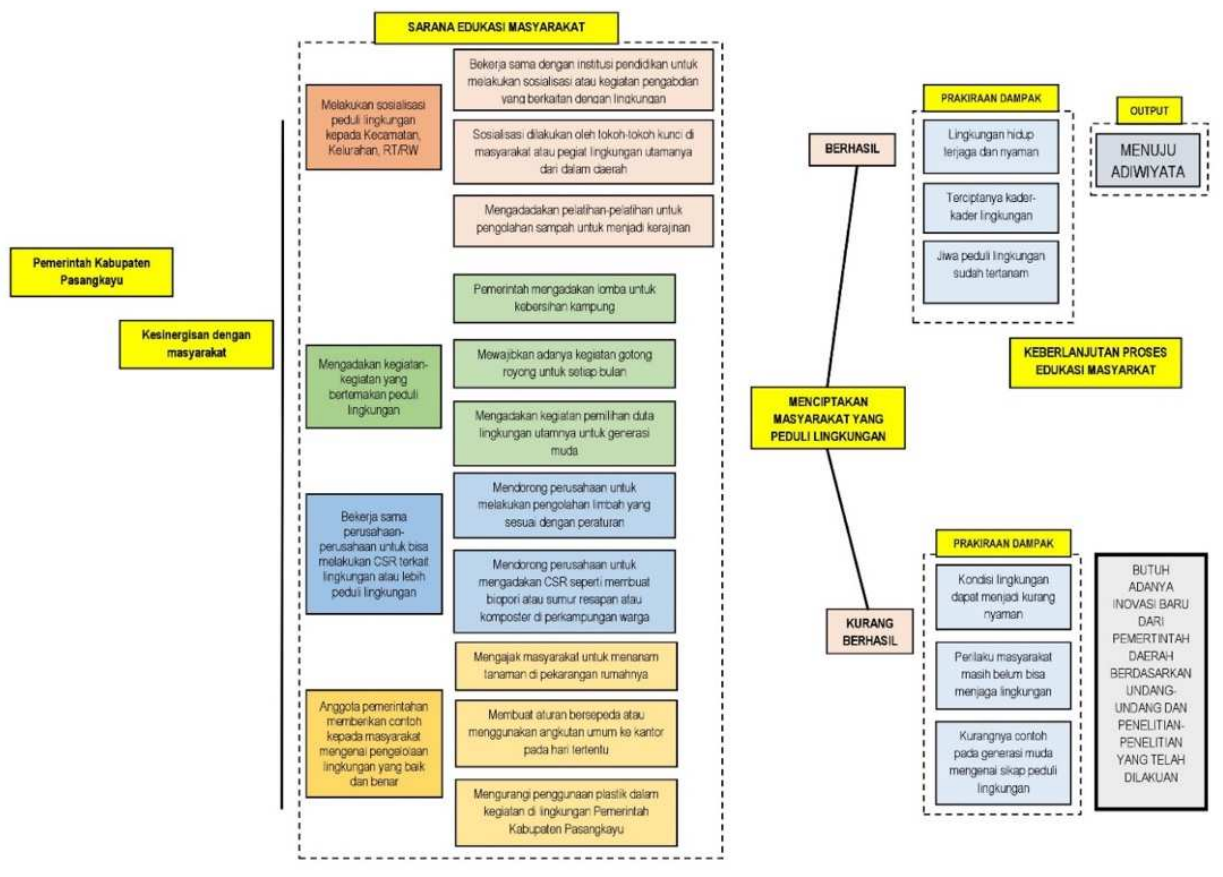

Fig. 2. Model 1 is to build a synergy with the community (Source: Pasangkayu District Government and the Community)

In Figure 2 showed Model 1 that requires synergy between Pasangkayu District Government and the Community. The purpose of model 1 is to educate and approach the community so that they understand about environmental management and protection in various aspects of their lives. So hopefully, it will create a community that cares about the environment. People who care about the environment are showed in their daily actions that they have more responsibility to the environment [8]. The role of the community is inseparable from the means of education through families who will be able to shape the nature of caring for the environment from an early age and create environmental care attitudes from the younger generation. This is because formal and informal education is one of the main solutions to grow the foundation of environmental care for the community, especially the younger generation so that they have a good and correct understanding [8][9]. Model 1 expect to bring the community to indirectly 
participate in achieving the standards of Adiwiyata, namely the implementation of an environment-based curriculum in which explains that educators have competence in developing environmental learning activities and students do learning activities about environmental protection and management. To be able to achieve one of these standards can be started from forming a community that cares about the environment, so that environmental management and protection activities will be more sustainable. According to Landriany [10] and Adam [11], to be able to increase environmental awareness, the government and schools must involve elements of society such as RT, RW, and Village in activities related to the environment. The relationship between schools and the community is very important, because schools are inseparable from the lives of the people so that schools are an integral part of society, the community is the key to survival in the school, the function of the school is an educational institution to be able to serve the community, and the school is a manifestation of community needs for education [12].

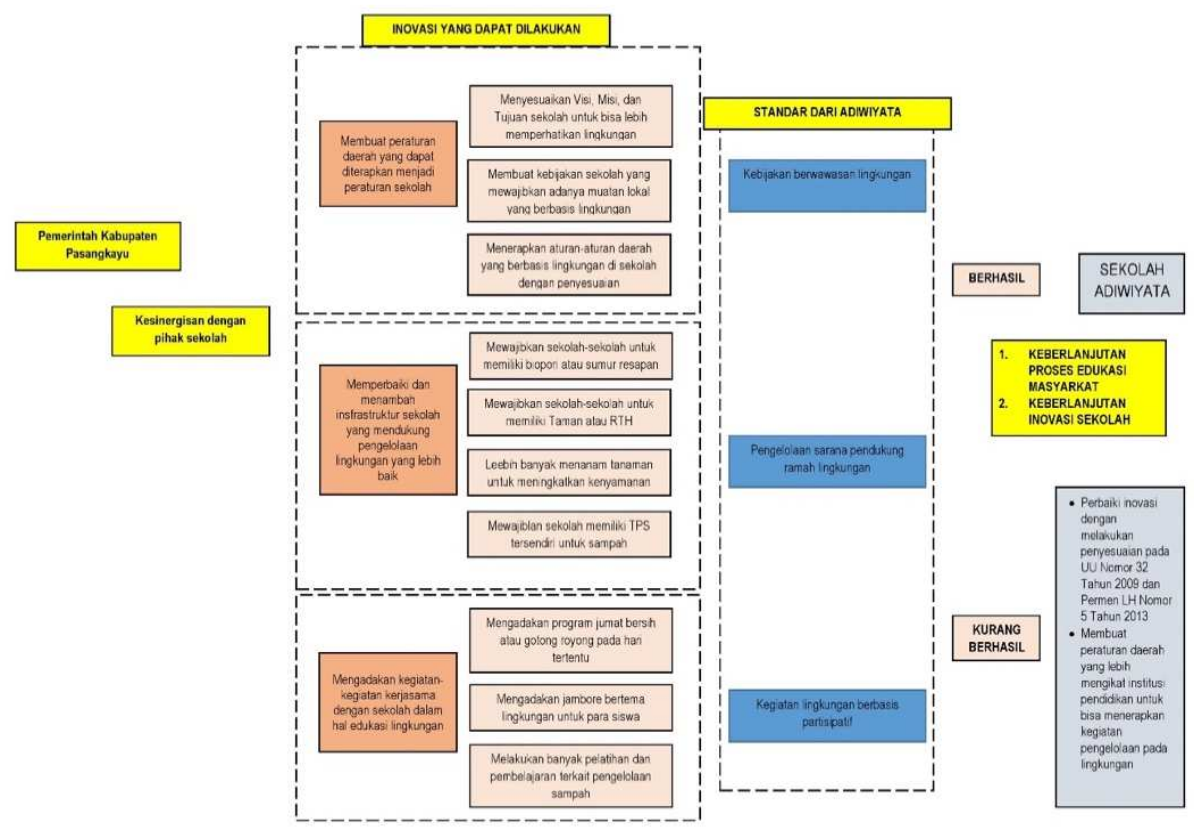

Fig. 3. Model 2 is to build synergy with the School community (Source: Pasangkayu District Government and the Community)

In Figure 3 showed Model 2. In this model, synergy is formed with the school. To be able to realize the Adiwiyata program in Pasangkayu Regency, there are several innovations that might be possible. These innovations are related to Adiwiyata's standards. In Model 1, the link between the second standard is explained, namely the implementation of an environment-based curriculum. In Model 2, it will focus more on the other three standards, namely environmentally friendly policies, participatory environment-based activities, and management of environmentally friendly supporting facilities. Innovation for the first standard regarding 
environmentally friendly policies is by making regional regulations that can later be applied as school regulations through school principals, these rules must also be based on the UndangUndang Nomor 32 Tahun 2009 about Environmental Protection and Management. Innovations that can be made to reach the third standard are to hold activities related to environmental education with the government and with other environmental conservation institutions. As for the fourth standard, innovations that can be done are to improve or add school infrastructure or facilities to support environmental management programs such as making biopore, green space, infiltration wells, and others. With the sustainable synergy between the Regional Government with community and schools, it can actualize Adiwiyata school and be able to form cadres concerned about the environment, especially the younger generation. Based on research from Rahmah [13], one of the obstacles that may occur in the Adiwiyata school development is the lack of integration of teachers and other school equipment in carrying out activities related to environmental protection and management. In addition, the government through direct policy to the principal can require the formation of the Adiwiyata team, conduct environmental studies, and action plans [14].

Collaboration in achieving the Adiwiyata school target must be carried out by all elements of the school both inside and outside the school which includes the Principal, School Committee, parents or guardians, students, teachers, staff, and surrounding communities, because each element has its own role - in realizing environmental [15][16]. The role of the teacher and the principal is very large in shaping the character of students [17], explains that the teacher's behavior in teaching is one of the things imitated by students. This is because students tend to imitate the behavior or actions of someone who is respected and loved [18]. In order to be more synergic between the role of government with the role of the community and schools, socialization needs to be done. Socialization is an important step that can be taken to increase cooperation from schools and the community to realize the Adiwiyata school in Pasangkayu Regency.

\section{Conclusion}

Based on this research, there are at least two models that can be developed and implanted in Pasangkayu Regency to actualize an Adiwiyata School. The fist model requires synergy between Pasangkayu District Government and the Community, while for the second model it needs synergy is formed with the school. The policies and actions that can be taken by the Pasangkayu Regency Government generally need more synergize system between local government policies with community and schools. It is an option to encourage the emergence of people who care about the environment so they can reach the standards of Adiwiyata in accordance with applicable regulations.

\section{References}

[1] S. Hamzah, "Pendidikan Lingkungan: Sekelumit Wawasan Pengantar," Bandung: Refika Aditama, 2013.

[2] W. S. M. Sumardi and M. Widyastuti, "Dasar-Dasar Perlindungan Hutan.” Yogyakarta: Gajah Mada University Press, 2004.

[3] I. Rachman, "Multimedia Berbasis Problem Based Learning pada Pembelajaran PLH untuk 
Membangun Kesadaran Siswa," EDUTECH, vol. 16, no. 1, pp. 1-21.

[4] Kementerian Lingkungan Hidup (KLH), Panduan Adiwiyata. Jakarta: Kementerian Lingkungan Hidup Republik Indonesia, 2012.

[5] W. Surakusumah, "Konsep pendidikan lingkungan di sekolah: model uji coba sekolah berwawasan lingkungan,” Pendidik. Biol. UPI, 2009.

[6] E. Sulistyowati, "Implementasi kurikulum pendidikan karakter," Yogyakarta Citra Aji Parama, 2012.

[7] J. Lofland, D. Snow, L. Anderson, and L. H. Lofland, "Analyzing Social Settings: A Guide to Qualitative Observation and Analysis (Belmont, CA: Wadsworth/Thomson Learning)." Inc, 2006.

[8] M. Desfandi, "Mewujudkan masyarakat berkarakter peduli lingkungan melalui program adiwiyata," SOSIO-DIDAKTIKA Soc. Sci. Educ. J., vol. 2, no. 1, pp. 31-37, 2015.

[9] S. Sumarmi, "Sekolah Hijau Sebagai Alternatif Pendidikan Lingkungan Hidup dengan Menggunakan Pendekatan Kontekstual," J. Ilmu Pendidik., vol. 15, no. 1, 2016.

[10] E. Landriany, "Implementasi kebijakan adiwiyata dalam upaya mewujudkan pendidikan lingkungan hidup di SMA Kota Malang," J. Kebijak. dan Pengemb. Pendidik., vol. 2, no. 1, 2014.

[11] A. F. B. Adam, "Analisis implementasi kebijakan kurikulum berbasis lingkungan hidup pada program adiwiyata mandiri di SDN Dinoyo 2 malang," J. Kebijak. dan Pengemb. Pendidik., vol. 2, no. 2, 2014

[12] N. Purwanto, “Administrasi Supervisi Pendidikan,” PT Remaja Rosdakarya Bandung, 2006.

[13] Y. D. Rahmah, "Implementasi Program Sekolah Adiwiyata (Studi pada Sekolah Dasar Negeri Manukan Kulon III/540 Kota Surabaya)," J. Adm. Publik, vol. 2, no. 4, pp. 453-757, 2014.

[14] A. Syaikhudin, "Menuju Sekolah Adiwiyata: Implementasi Pendidikan Lingkungan Hidup di SDN Bangunsari," J. Islam. Elem. Sch., vol. 1, no. 2, pp. 42-52, 2016.

[15] I. K. Pradini, B. Sudjanto, and N. Nurjannah, "Implementasi program sekolah adiwiyata dalam peningkatan mutu pendidikan di SDN Tanah Tinggi 3 Kota Tangerang," J. Green Growth Dan Manaj. Lingkung., vol. 7, no. 2, pp. 122-132, 2018.

[16] S. P. H. Warju and M. D. H. Soenarto, "Evaluating the Implementation of Green School (Adiwiyata) Program: Evidence from Indonesia," Int. J. Environ. Sci. Educ., 2017.

[17] N. A. Putri, "Penanaman Nilai-Nilai Pendidikan Karakter Melalui Mata Pelajaran Sosiologi," Komunitas Int. J. Indones. Soc. Cult., vol. 3, no. 2, 2011.

[18] S. Clayton and G. Myers, Conservation psychology: Understanding and promoting human care for nature. John Wiley \& Sons, 2015. 